\title{
Normalization of fasting hyperglycaemia by exogenous glucagon-like peptide 1 (7-36 amide) in Type 2 (non-insulin-dependent) diabetic patients
}

\author{
M.A.Nauck ${ }^{1}$, N.Kleine ${ }^{2}$, C. Ørskov ${ }^{3}$, J.J.Holst ${ }^{3}$, B. Willms ${ }^{2}$, W. Creutzfeldt ${ }^{1}$ \\ ${ }^{1}$ Division of Gastroenterology and Endocrinology, Department of Medicine, Georg-August-University, Göttingen, Germany \\ ${ }^{2}$ Fachklinik für Diabetes und Stoffwechselkrankheiten, Bad Lauterberg, Germany \\ ${ }^{3}$ Departments of Anatomy B and Physiology C, Panum Institute, Copenhagen, Denmark
}

\begin{abstract}
Summary. Glucagon-like peptide 1 (GLP-1) (7-36 amide) is a physiological incretin hormone that is released after nutrient intake from the lower gut and stimulates insulin secretion at elevated plasma glucose concentrations. Previous work has shown that even in Type 2 (non-insulindependent) diabetic patients GLP-1 (7-36 amide) retains much of its insulinotropic action. However, it is not known whether the magnitude of this response is sufficient to normalize plasma glucose in Type 2 diabetic patients with poor metabolic control. Therefore, in 10 Type 2 diabetic patients with unsatisfactory metabolic control $\left(\mathrm{HbA}_{1 \mathrm{c}}\right.$ $11.6 \pm 1.7 \%$ ) on diet and sulphonylurea therapy (in some patients supplemented by metformin or acarbose), $1.2 \mathrm{pmol}$ $\times \mathrm{kg}^{-1} \times \min ^{-1}$ GLP -1 (7-36 amide) or placebo was infused intravenously in the fasting state (plasma glucose $13.1 \pm 0.6 \mathrm{mmol} / \mathrm{l}$ ). In all patients, insulin (by $17.4 \pm 4.7 \mathrm{nmol}$ $\times 1^{-1} \times \min ; p=0.0157$ ) and C-peptide (by $228.0 \pm 39.1$ nmol $\left.\times 1^{-1} \times \min ; p=0.0019\right)$ increased significantly over
\end{abstract}

basal levels, glucagon was reduced (by $-1418 \pm 308 \mathrm{pmol}$ $\times 1^{-1} \times \min$ ) and plasma glucose reached normal fasting concentrations $(4.9 \pm 0.3 \mathrm{mmol} / \mathrm{l})$ within $4 \mathrm{~h}$ of GLP-1 (7-36 amide) administration, but not with placebo. When normal fasting plasma glucose concentrations were reached insulin returned towards basal levels and plasma glucose concentrations remained stable despite the ongoing infusion of GLP-1 (7-36 amide). Therefore, exogenous GLP-1 (7-36 amide) is an effective means of normalizing fasting plasma glucose concentrations in poorly-controlled Type 2 diabetic patients. The glucose-dependence of insulinotropic actions of GLP-1 (7-36 amide) appears to be retained in such patients.

Key words: Type 2 (non-insulin-dependent) diabetes mellitus, incretin hormones, glucagon-like peptide 1 (7-36 amide), pancreatic glucagon, enteroinsular axis.
Glucagon-like peptide 1 (7-36 amide) is an insulinotropic hormone secreted from enteroglucagon-producing cells in the lower gut, i.e. the distal jejunum, ileum and colon/rectum [1]. Since after meals plasma concentrations increase and reach the concentration range necessary to stimulate insulin secretion, GLP-1 (7-36 amide), together with gastric inhibitory polypeptide (GIP) from the upper gut, act as physiological incretin hormones [2,3]. In pharmacological concentrations, exogenous GLP-1 (7-36 amide or 7-37) raised insulin and lowered glucagon concentrations also in Type 2 (non-insulin-dependent) diabetic patients $[4,5]$. It also reduced meal-related insulin requirements in both Type 1 (insulin-dependent) and Type 2 diabetic patients [6]. However, after a mixed meal, not only influences on insulin and glucagon secretion, but also other effects, such as an inhibition of gastric emptying may have contributed to the "anti-diabetogenic effect" [7]. Therefore, the aim of the present study was to characterize the endocrine pancreatic and glucose response to a pharmacological dose of exogenous GLP-1 (7-36 amide) in fasting Type 2 diabetic patients. The subjects were selected to represent a group of Type 2 diabetic patients which could not be satisfactorily controlled by oral antidiabetic drugs. Since the expected insulinotropic response involves the potential risk of hypoglycaemic reactions, it was of special interest to evaluate the glucose-dependence of the insulin response to GLP-1 (7-36 amide) in these patients, i.e. to see whether the insulin response declines again when normal fasting glucose concentrations are approached.

\section{Subjects, materials and methods}

\section{Study protocol}

The study protocol was approved by the ethics committee of the medical faculty of the Georg-August-University, Göttingen prior to the study. Written informed consent was obtained from all participants. 
Table 1. Patient characteristics

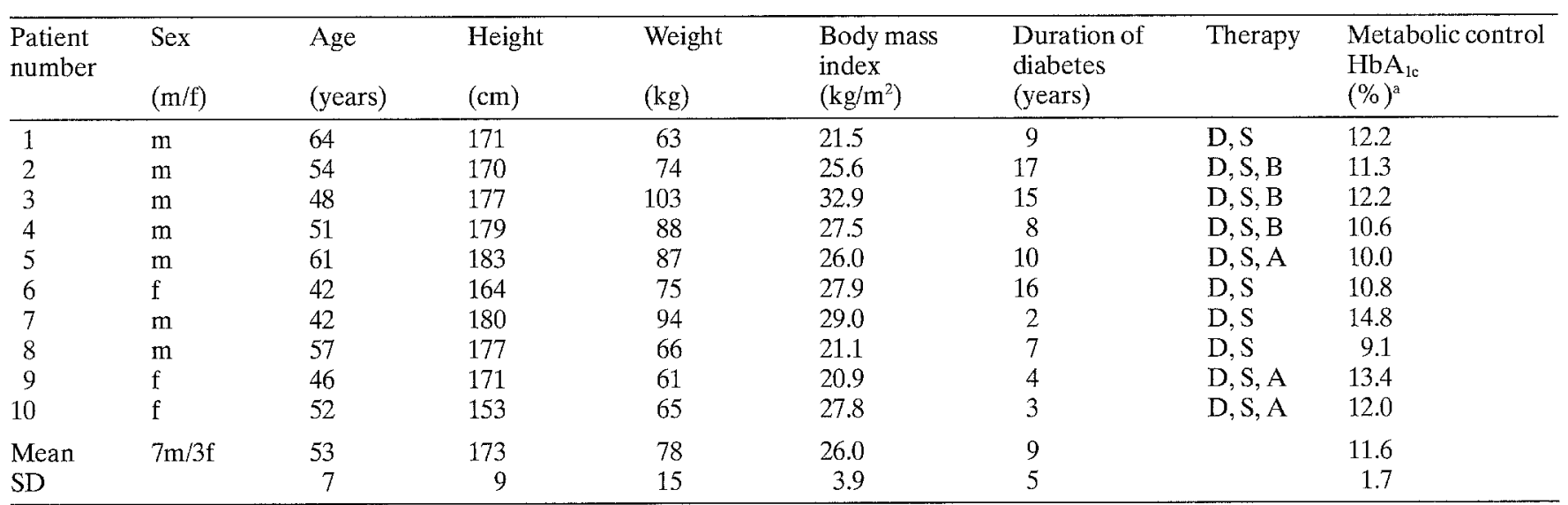

D, Diet; S, sulphonylurea treatment (glibenclamide, $10.5 \mathrm{mg}$ per day); B, biguanide treatment (metformin, $1700 \mathrm{mg}$ or $2550 \mathrm{mg}$ per day), A, acarbose treatment (300 mg per day). ${ }^{a}$ normal value: $4.0-6.2 \%$

\section{Patients}

Ten Type 2 diabetic patients were studied (Table 1 ). They were all being treated with diet and sulphonylurea compounds, and some were also receiving metformin or acarbose treatment. Multiple fasting plasma glucose concentrations (from hospital charts) were $13.1 \pm 2.0 \mathrm{mmol} / \mathrm{l}(236 \pm 36 \mathrm{mg} / \mathrm{dl})$, postprandial glucose concentrations were $15.1 \pm 2.7 \mathrm{mmol} / \mathrm{l}(272 \pm 49 \mathrm{mg} / \mathrm{dl})$. Because of unsatisfactory metabolic control, eight of these ten patients were assigned to insulin treatment immediately after the study.

The patients were studied on two occasions. All anti-diabetic medication was continued until the morning before the studies. A regular meal and drug schedule was allowed for one day between the experiments with GLP-1 (7-36 amide) and placebo. On the study days, all medication was withheld until the end of the experiments.

\section{Peptides}

Synthetic GLP-1 (7-36 amide) was purchased from Saxon Biochemicals GmbH, Hannover, FRG. The same lot number was used as in previous studies (GLP-1 (7-36 amide): PGAS 242, Lot ZE 865, net peptide content $79.3 \%$ ) $[3,4]$. The peptide was dissolved, filtered through $0.2 \mu \mathrm{m}$ nitrocellulose filters (Millipore, Bedford, Mass., USA) and stored frozen at $-30^{\circ} \mathrm{C}$ as previously described. Net peptide content rather than gross weight was used for dose calculations. HPLC profiles (provided by the manufacturer) showed that the preparation was more than $99 \%$ pure (single peak coeluting with appropriate standards). Samples were analysed for bacterial growth (standard culture techniques) and for pyrogens (Limulus amebocyte lysate endo-LAL; Chromogenix AB, Mölndal, Sweden). No bacterial contamination was detected. Endotoxin concentrations in the GLP-1 (7-36 amide) stem solutions were always less than $0.03 \mathrm{EU} / \mathrm{ml}$.

\section{Experimental procedures}

The experiments were performed in randomized wrder. The tests were performed in the morning after an overnight fast. Two forearm veins were punctured with a teflon cannula (Moskito 123, 18 gauge; Vygon, Aachen, FRG), which was kept patent using $0.9 \% \mathrm{NaCl}$ (for blood sampling and for GLP-1 (7-36 amide)/placebo administration).

After drawing basal blood specimens at $0 \mathrm{~min}$, an intravenous infusion of GLP-1 (7-36 amide) or placebo $(0.9 \% \mathrm{NaCl}$ containing $1 \%$ human serum albumin; Merieux, Norderstedt, FRG) was started at an infusion rate of $1.2 \mathrm{pmol} / \mathrm{kg}$ per min and continued for $240 \mathrm{~min}$. Blood was drawn at 30 -min intervals and plasma glucose was determined immediately.

\section{Blood specimens}

Blood was drawn into heparinized tubes (immunoreactive (IR) insulin and C-peptide measurements). A sample was stored in $\mathrm{NaF}$ (Microvette CB 300; Sarstedt, Nümbrecht, FRG) for the measurement of glucose. For glucagon and GLP-1 (7-36 amide) measurements blood was drawn into tubes containing EDTA and aprotinin (Trasylol; 20000 kallikrein inhibition units $/ \mathrm{ml}, 200 \mu \mathrm{l}$ per $10 \mathrm{ml}$ blood; Bayer AG, Leverkusen, FRG). After centrifugation, plasma for hormone analyses was kept frozen at $-30^{\circ} \mathrm{C}$.

\section{Laboratory determinations}

Glucose was measured using a glucose oxidase method with a Glucose Analyser 2 (Beckman Instruments, Munich, FRG). Plasma IRinsulin and C-peptide were determined using commercial radioimmunoassay kits (Insulin RIA 100; Pharmacia, Freiburg, FRG; RIAmat C-peptide II, Byk-Sangtec Diagnostika, Dietzenbach, FRG), with human insulin and C-peptide as standard.

IR-GLP-1 was determined in ethanol-extracted plasma as previously described [8], using antiserum 2135 (final dilution 1:150000) and synthetic GLP-1 (7-36 amide) for tracer preparation and as standard. Recovery of GLP-1 (7-36 amide) standards after alcohol extraction was $75 \pm 8 \%$. The experimental detection limit ( 2 SD over samples not containing GLP-1 (7-36 amide)) was less than $5 \mathrm{pmol} / \mathrm{l}$. Antiserum 2135 binds, with approximately equal affinity, to all proglucagon-derived peptides containing the GLP-1 (7-36 amide) sequence, regardless of amino- or carboxy-terminal extensions. Pancreatic glucagon was assayed in ethanol-extracted plasma using antibody 4305 [9].

Non-esterified fatty acids were quantitated enzymatically with acyl-CoA oxidase from Candida tropicalis using a Hitachi 705 autoanalyser. Reagents were from Wako Chemicals (Neuss, FRG).

Each patient's set of plasma samples was assayed at the same time to avoid errors due to inter-assay variation.

\section{Statistical analysis}

Results are reported as mean \pm SEM. Integration was carried out according to the trapezoidal rule. Significances of differences were tested using repeated measurement analysis of variance (RMANOVA; NCSS Version 5.01, Kaysville, Utah, USA). If a significant interaction of treatment and time was documented $(p<0.05)$, values at single time points were compared by Student's $t$-test (paired analyses). $P$-values were corrected for the number of comparisons made according to Bonferroni-Holm. A corrected two-sided $p$-value less than 0.05 was taken to indicate significant differences. 

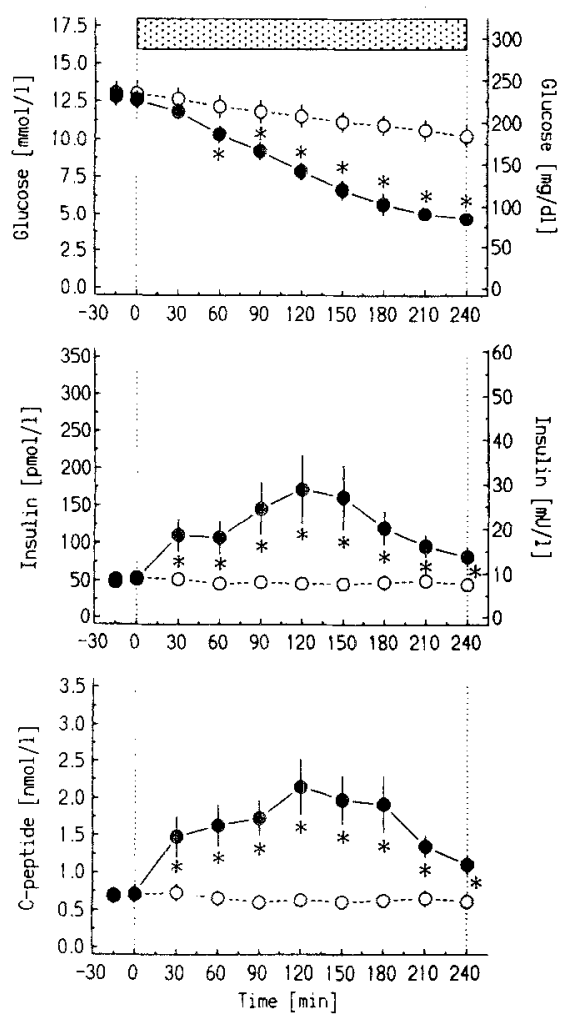

Fig. 1. Plasma glucose (upper panel), insulin (middle panel) and Cpeptide (lower panel) responses to the intravenous administration of glucagon-like peptide 1 (GLP-1) (7-36 amide) (1.2 pmol/kg per min) or placebo in 10 Type 2 diabetic patients. Mean \pm SEM are given. : experiments with GLP-1 (7-36 amide). O: experiments with placebo. The dotted bar indicates the duration of exogenous administration of GLP-1 (7-36 amide) or placebo. RM-ANOVA indicated significant interactions of treatment (GLP-1 (7-36 amide) vs placebo) and time $(p<0.0001)$ regarding glucose, insulin, and $C$ peptide measurements. Asterisks indicate significant differences at single time points $(p<0.05)$

\section{Results}

The mean fasting plasma glucose concentrations before the exogenous administration of GLP-1 (7-36 amide) was $12.7 \pm 0.6 \mathrm{mmol} / \mathrm{l}$. GLP-1 (7-36 amide) lowered plasma glucose in all 10 Type 2 diabetic patients (Fig.1). After $240 \mathrm{~min}$, "normal" basal plasma concentrations were reached $(4.9 \pm 0.3 \mathrm{mmol} / 1)$, whereas with placebo, only a slight reduction in plasma glucose concentrations was noted $(10.4 \pm 0.7 \mathrm{mmol} / \mathrm{l} ; \quad p=0.0025$ by $\mathrm{RM}$ ANOVA). Both insulin and C-peptide increased significantly during the intravenous infusion of GLP-1 (736 amide). The integrated incremental response of insulin amounted to $17.4 \pm 4.7 \mathrm{nmol} \times 1^{-1} \times \min (p=$ 0.0157 ), and of C-peptide to $228.0 \pm 39.1 \mathrm{nmol} \times \mathrm{I}^{-1} \times \min$ $(p=0.0019)$.

When plasma glucose values approached normal basal plasma glucose values, insulin and C-peptide values decreased again. Plasma glucose did not fall further. In a subgroup of five patients, who had reached a normal basal plasma glucose concentration by $180 \mathrm{~min}$, a stable plasma glucose concentration of $4.1 \pm 0.2 \mathrm{mmol} / 1$ was maintained over the last hour of the experiment despite an ongoing GLP-1 (7-36 amide) infusion (details not shown). The
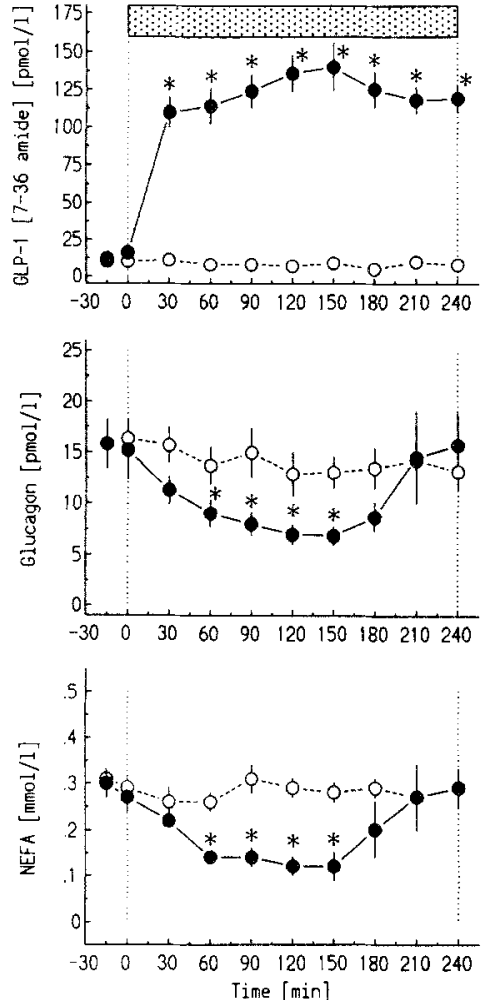

Fig. 2. Plasma glucagon-like peptide 1(GLP-1) (7-36 amide) (upper panel), pancreatic glucagon (antibody 4305; middle panel) and nonesterified fatty acid (NEFA; lower panel) responses to the intravenous administration of GLP-1 (7-36 amide) (1.2 pmol/kg per min) or placebo in 10 Type 2 diabetic patients. Mean \pm SEM are given. 0 : experiments with GLP-1 (7-36 amide). O: experiments with placebo. The dotted bar indicates the duration of exogenous administration of GLP-1 (7-36 amide) or placebo. RM-ANOVA indicated significant interactions of treatment (GLP-1 (7-36 amide) vs placebo) and time regarding GLP-1 ( $7-36$ amide) $(p<0.0001)$, pancreatic glucagon $(p=0.0009)$, and NEFA $(p<0.0001)$ measurements. Asterisks indicate significant differences at single time points $(p<0.05)$

lowest plasma glucose recorded at any time point was $3.5 \mathrm{mmol} / \mathrm{l}$.

The steady-state concentration of GLP-1 (7-36 amide) was $123 \pm 10 \mathrm{pmol} / \mathrm{l}$ with exogenous GLP-1 (7-36 amide). With placebo, the values remained in the basal range ( $8 \pm 1$ pmol/l;; Fig. 2 , upper panel)

Pancreatic glucagon was significantly lowered with exogenous GLP-1 (7-36 amide) by $-1418 \pm 308 \mathrm{pmol}$ $\times 1^{-1} \times \min$; Fig. 2 , middle panel) despite a considerable fall in plasma glucose (Fig. 1, upper panel). When plasma glucose approached normal fasting levels, glucagon returned to baseline values.

During the exogenous administration of GLP-1 (7-36 amide), plasma non-esterified fatty acids significantly decreased (by $-26.3 \pm 3.1 \mathrm{mmol} \times 1^{-1} \times$ min) during the period characterized by elevated insulin and reduced glucagon concentrations (Fig. 2, lower panel; $p=0.028$ ).

\section{Discussion}

The results of the present study indicate that the preserved incretin activity of GLP-1 (7-36 amide) may be utilized to normalize fasting plasma glucose concentrations in Type 2 
diabetic patients. This is an extension of previous observations where, in mildly Type 2 diabetic patients, GLP-1 (736 amide) as an insulinotropic agent was found to be almost equally as effective as in age-and weight-matched normal subjects [4]. Therefore, the insulinotropic effect of GLP-1 (7-36 amide) is of sufficient magnitude to reduce elevated plasma glucose concentrations into the normal fasting range even in patients who no longer respond well to oral anti-diabetic drugs. The concentrations of GLP-1 (736 amide) reached with an infusion rate of $1.2 \mathrm{pmol} \times \mathrm{kg}^{-1}$ $\times \min ^{-1}$ were approximately two-to three-fold higherthan peak values measured after oral glucose when using the same radioimmunoassay $[3,4]$. Therefore, the actions of GLP-1 (7-36 amide) observed in the present study are pharmacological effects, although the difference in circulating concentrations to those encountered under physiological conditions was not great.

The amount of insulin secreted in response to GLP-1 (7-36 amide) can be estimated to be approximately $11.9 \pm 2.3 \mathrm{U}[10]$. The glucagon-lowering effect of GLP-1 (7-36 amide) $[4,11-13]$ may contribute to the normalization of plasma glucose concentrations. However, when considering the different glucose concentration curves in the GLP-1 (7-36 amide) and placebo experiments, the influence of GLP-1 (7-36 amide) on pancreatic alpha cell secretion cannot be judged without accounting for the influence of glucose itself. The elevation in insulin concentrations may have contributed to the reduction in pancreatic glucagon. However, in some patients insulin and C-peptide increased very little. Nevertheless, glucagon concentrations were lowered and glucose concentrations were normalized (details not shown). This indicates that alpha-cell inhibition contributes to the effect on plasma glucose concentrations. Additional experiments will have to weigh the relative contributions of increased beta-cell and reduced alpha-cell secretion.

In agreement with the strict glucose-dependence of insulinotropic actions of GLP-1 (7-36 amide) reported in normal subjects $[2,3,12]$, when the Type 2 diabetic patients were hyperglycaemic, insulin and C-peptide concentrations were stimulated, with a return towards basal levels when glucose concentrations approached normal fasting levels. This shows that even in poorly-controlled diabetic patients, whose plasma glucose concentrations have not been normal over a prolonged period, a similar glucose threshold exists for the insulinotropic action of GLP-1 (7-36 amide) as seen in normal subjects. This should limit the risk of hypoglycaemic responses when GLP-1 (7-36 amide) or similarly acting analogues are used as therapeutic agents.

After meals, other actions of GLP-1 (7-36 amide) may help to reduce the postprandial increment in plasma glucose. GLP-1 (7-36 amide) slows the velocity of gastric emptying and thereby reduces the availability of nutrients for absorption [7]. In addition, the rise in glucose and glucagon concentrations and in meal-related insulin requirements are decreased after a test meal in Type 1 and Type 2 diabetic patients [6].

In conclusion, in the fasting state, exogenous GLP-1 (7-36 amide) stimulates insulin and reduces glucagon secretion to a degree that leads to a normalization of plasma glucose concentrations even in poorly-controlled Type 2 diabetic patients with secondary failure after sulphonylurea treatment. Furthermore, the strict glucose-dependence of insulinotropic effects limits the amount of insulin secreted when high doses of GLP-1 (7-36 amide) are administered at near-normal fasting plasma glucose concentrations.

Acknowledgements. The excellent technical assistance of Ms. S. Bierkamp, S. Ogilvie, A.Bernhard, W.Kopp, K. Illmer, M. Stix, and L.Rabenhøj is gratefully acknowledged. We thank Priv.-Doz. Dr. V. Armstrong for the NEFA-measurements. This study was supported by the Deutsche Forschungsgemeinschaft, Bonn 2 (Bad Godesberg), grant $\mathrm{Na} 203 / 2-2$, by the Danish Medical Research Council, and by the Novo Nordisk Foundation.

\section{References}

1. Eissele R, Göke R, Willemer S et al. (1992) Glucagon-like peptide 1 cells in the gastrointestinal tract and pancreas of rat, pig and man. Eur J Clin Invest 22: 283-291

2. Kreymann B, Ghatei MA, Williams G, Bloom SR (1987) Glucagon-like peptide 17-36: a physiological incretin in man. Lancet II: $1300-1304$

3. Nauck M, Bartels E, Ørskov C, Ebert R, Creutzfeldt W (1993) Additive insulinotropic effects of exogenous synthetic human gastric inhibitory polypeptide and glucagon-like peptide 1 (736 amide) infused at near-physiological insulinotropic hormone and glucose concentrations. J Clin Endocrinol Metab 76:912-917

4. Nauck MA, Heimesaat MM, Ørskov C, Holst JJ, Ebert R, Creutzfeldt W (1993) Preserved incretin activity of glucagon-like peptide 1 (GLP-1) (7-36 amide) but not of synthetic human gastric inhibitory polypeptide (GIP) in patients with Type 2 diabetes mellitus. J Clin Invest 91: 301-307

5. Nathan DM, Schreiber E, Fogel H, Mojsov S, Habener JF (1992) Insulinotropic action of glucagon-like peptide-I-(7-36) in diabetic and nondiabetic subjects. Diabetes Care 15:270-276

6. Gutniak M, Ørskov C, Holst JJ, Ahren B, Efendic S (1992) Antidiabetogenic effect of glucagon-like peptide-1 (7-36)amide in normal subjects and patients with diabetes. N Engl J Med 326: $1316-1322$

7. Wettergen A, Scholdager B, Mortensen PE, Myhre J, Christiansen J, Holst JJ (1990) Truncated GLP-1 (proglucagon 87-107 amide) from distal gut: role in regulation of gastric and pancreatic functions. Digestion 46 [Suppl 1]: 120 (Abstract)

8. Ørskov C, Holst JJ (1987) Radio-immunoassays for glucagonlike peptides 1 and 2(GLP-1 and GLP-2). Scand J Clin Lab Invest 47:165-174

9. Holst JJ (1982) Evidence that peak II GLI or enteroglucagon is identical to the C-terminal sequence (residues 33-69) of glicentin. Biochem J 207: 381-388

10. Polonsky KS, Given BD, Hirsch LJ et al. (1988) Abnormal patterns of insulin secretion in noninsulin-dependent diabetes mellitus. N Engl J Med 318: 1231-1239

11. Ørskov C, Holst JJ, Nielsen OV (1988) Effect of glucagon-like peptide 1 (proglucagon (78-107) amide) on endocrine secretion from pig pancreas, antrum and nonantral stomach. Endocrino$\log$ 123: 2009-2013

12. Komatsu R, Matsuyama T, Namba M et al. (1989) Glucagonostatic and insulinotropic action of glucagonlike peptide 1-(7-36)amide. Diabetes 38: 902905

13. Ørskov C(1992) Glucagon-like peptide-1, a new hormone of the entero-insular axis. Diabetologia 35: 701-711

Received: 30 November 1992

and in revised form: 19 March 1993

Dr. M. Nauck

Medizinische Klinik der Ruhr-Universität

im Knappschafts-Krankenhaus

In der Schornau 23-25

D-44892 Bochum

Germany 